\title{
Diallyl-n-Sulfide of Garlic Inhibits Glycogenolysis in Heat-Stressed Laying Sentul Chicken
}

\section{A. Mushawwir, D. Latipudin, R. Permana, and N. Suwarno}

\author{
Animal Science Faculty, University of Padjadjaran Jl. Raya Sumedang KM. 21 Bandung-Sumedang, \\ Jatinangor Sumedang, West Java, Indonesia. \\ Corresponding Author: mushawwir@unpad.ac.id
}

\begin{abstract}
Heat stress causes a decrease in metabolic function and immunity, which results in a decrease in production. The provision of natural extracts such as the active compound dyally n-suldifa (Dn-S) is one strategy to overcome the adverse effects of heat stress. One hundred and twenty five female laying native chickens, with an average body weight of $1213.83 \pm 15.52 \mathrm{~g}$, 40 weeks old, were used in this experiment, to study the impact of Dn-S administration from garlic on the metabolite profile of the glycogenolysis pathway. laying. Laying hens were distibuted into five treatment groups, each with 25 samples. Dn-S isolation from garlic isolated by distillation technique. The study was carried out with five types of experimental treatments, as follows the group with a comfort zone temperature $\left(24^{\circ} \mathrm{C}\right)$ and without the administration of Diallyl n-Sulfide (Dn-S), heat stress $\left(38^{\circ} \mathrm{C}\right)$ and without Dn-S, heat stress $\left(38^{\circ} \mathrm{C}\right)$ and $100 \mu \mathrm{L}$ Dn-S, heat stress $\left(38^{\circ} \mathrm{C}\right)$ and $125 \mu \mathrm{L}$ Dn-S, heat stress $\left(38^{\circ} \mathrm{C}\right)$ and $150 \mu \mathrm{L} \mathrm{Dn-S/head.} \mathrm{Based} \mathrm{on} \mathrm{the} \mathrm{results} \mathrm{of} \mathrm{the} \mathrm{study,} \mathrm{it} \mathrm{was} \mathrm{shown} \mathrm{that} \mathrm{heat} \mathrm{stress} \mathrm{causes} \mathrm{an} \mathrm{increase} \mathrm{in} \mathrm{the}$ rate of glycogenolysis and intermediate metabolites and their catalyzing enzymes. It appears that the administration of $150 \mu \mathrm{L}$ Dn-S, effectively reduces the rate of glycogenolysis. It was concluded that heat stress on laying hens could be avoid by administering garlic Dn-S.
\end{abstract}

Keywords : Diallyl n-Sulfide Glycogenolysis, heat-stressed

\section{INTRODUCTION}

Sentul chikens have been developed and cultivated throughout Indonesia for a long time. Based on the category of body temperature adaptation, chickens are classified as homothermic animals. This group of animals, physiologically has a system that is able to maintain the normal range of body temperature, which is $38-39^{\circ} \mathrm{C}$. However, chickens have a comfortable environmental zone or the so-called thermoneutral zone to be able to express their genetic abilities, which is $21-25^{\circ} \mathrm{C}$.

Increasing environmental temperature is an important problem for the development and growth of quail. The environmental temperature above the comfort zone causes the physiological and biochemical processes to be directed more towards homeostasis (Mushawwir et al., 2010, 2011, 2020a.b; Ammer et al., 2018). Homeostasis is increased in order to achieve a balanced degree of organ function and metabolic rate in order to regulate body heat (thermoregulation). This process has an impact on the shift in the function of energy, from the purpose of production to energy to fulfill the achievement of homeostasis. The longer exposure to heat stress, the lower feed intake (Allen et al., 2015; Istvan et al., 2020) so that energy adequacy is reduced.
On the other hand, heat stress also increases the risk of DNA mutation and denaturation of body proteins (enzymes, receptors, cell transporters, hormones). DNA mutations and protein denaturation are triggered by increased production of free radicals (Gehrke et al., 2013; Slimen et. al., 2016; Mushawwir et al., 2019) from mitochondrial oxidationreduction (cellular stress), and/or direct stress in the form of environmental heat radiation to the body of quail. This condition has a wide impact on metabolism, especially energy synthesis in the matrix in the mitochondria (Gray et al., 2015; Tian et al, 2015; Carrol et al., 2016).

The first step or stage of reshuffling the molecule in these circumstances, in order to meet energy is the reshuffle or catabolism of carbohydrate reserves (polysaccharides) in the cytoplasm, namely glycogen degradation. This catabolic reaction is known as glycogenolysis. The main purpose of this reaction is the formation of glucose into pyruvate, either with the help of oxygen (aerobic glycolysis), or without oxygen (anaerobic glycolysis).

One of the strategies adopted to reduce the impact of heat stress is the provision of natural feed additives, namely diallyn n-sulphide (Dn-S) from garlic (garlik). Dn-S is an volatile component that has reactive oxygen $(\mathrm{O})$ and sulfur (S) atoms to be able to bind to free radicals (Tian et al., 2015, Tanuwiria et al., 2020; 
Mushawwir et al., 2021c). It is hoped that with its reaction ability, it is able to prevent the bad effects of free radicals in lowering the metabolic rate. It is also expected to be able to overcome protein denaturation so that protein function can be optimal.

Therefore, it is important to study the impact of Dn-S administration in relation to the use of catalyzed glycogen reserves for energy fulfillment (glycogenolysis) under heat stress conditions.

Through this study, a hypothesis was established that administration of Dn-S was able to suppress the enzymes involved in the breakdown of glycogen or glycogenolysis in heat-stressed laying hens.

\section{MATERIAL AND METHODE}

\section{Animal and Experiment Design}

One hundred and twenty five (125)

Sentul Chickens, female, with an average body weight of $1213.83 \pm 15.52 \mathrm{~g}, 40$ weeks old, were used in this experiment. Sentul chicken samples were divided into five treatment groups, 25 each. Each treatment consisted of five replications, so that each replication consisted of 5 samples of Sentul Chicken.

The study was conducted with five types of experimental treatment, as follows:

A : Comfort zone temperature $\left(24^{\circ} \mathrm{C}\right)$ and without giving Diallyl n-Sulfide (Dn-S)

$B$ : Heat stress $\left(38^{\circ} \mathrm{C}\right)$ and without Dn-S

$\mathrm{C}$ : Heat stress $\left(38^{\circ} \mathrm{C}\right)$ and $100 \mu \mathrm{L}$ Dn-S/sample

$\mathrm{D}$ : Heat stress $\left(38^{\circ} \mathrm{C}\right)$ and $125 \mu \mathrm{L} \mathrm{Dn}-\mathrm{S} /$ sample

E : Heat stress $\left(38^{\circ} \mathrm{C}\right)$ and $150 \mu \mathrm{L}$ Dn-S/sample

The administration of Dn-S was carried out every morning before being given drinking water and rations, orally, fed directly into the cranial part of the oesophagus, using a micro pipette with a tip. Sentul chicken samples were placed in a single-level colony cage which was insulated based on the experimental unit. The experimental cage was made from a combination of wooden blocks and wire rang. The experimental cages used were 5 units. One drum unit consists of Sentul Chicken with a cage temperature according to the comfort zone, with a temperature range of $23-25^{\circ} \mathrm{C}$ or an average of $24^{\circ} \mathrm{C}$. The other four cages are equipped with incandescent lamps as a heat source and a thermostat, with a drum temperature range of 37$39^{\circ} \mathrm{C}$ or an average of $38^{\circ} \mathrm{C}$. Heat treatment is given at 07.00 in the morning until 20.00 in the evening.
Sentul chicken rations during the experiment were administered ad-libitum. The ration given was a commercial ration obtained from a poultry shop in Bandung. The composition of metabolic energy and nutrient rations are presented in Table 1.

Table 1. Content of Metabolic Energy and Nutrient in Experiment Ration

\begin{tabular}{lr}
\hline Metabolic Energy and Nutrient & composition \\
\hline Metabolic Energy (Kkal/kg) & 2741,52 \\
Crude Protein (\%) & 16,73 \\
Calsium (\%) & 3,31 \\
Phospor (\%) & 2,09 \\
Lysin (\%) & 1,85 \\
Methionine (\%) & 1,17 \\
Crude Fiber (\%) & 4,81 \\
Crude Fat (\%) & 6,25 \\
\hline
\end{tabular}

\section{Preparation of Diallyl n-Sulfide of Garlic}

The separation of diallyl compounds was carried out according to Block (1985) and Amin et al. (2014). The expected characteristics of diallyl isolates are physically clear with a slight yellow, specific odor of garlic, boiling point of $180^{\circ} \mathrm{C}$ and molecular weight ranging from 141.21 to 146.28 g.mol-1 (Mushawwir et al., 2020c, 2021a).

The sliced garlic sample was put into a round bottom flask then added aquadest until the entire sample was completely submerged in a long necked round bottom flask that had been assembled in a water distillation device.

Distillation is carried out in the first step at a temperature of $75-80^{\circ} \mathrm{C}$ and the next step for 4-5 hours at a temperature of $100^{\circ} \mathrm{C}$ (Block, 1985). The dially compound isolates obtained were analyzed using the GS/MS technique. The content of Dn-S isolated from garlic present in Table 2, as follow,

Table 2. Contents of Dn-S Isolated from Garlic*

\begin{tabular}{lcl}
\hline Contents Dn-S & $\%$ \\
\hline Diallyl sulfide & 13.63 & \\
Diallyl disulfide & 42.63 & \\
Diallyl trisulfide & 19.53 & \\
Diallyl tetrasulfide & 6.36 & \\
Methyl allyl disulfide & 9.74 & \\
Methyl allyl trisulfide & 2.84 & \\
UNK & 1.60 & \\
UNK & 0.52 & \\
UNK & 1.11 & \\
\hline UNK: Unknnown, *analyzed in & Indosain Lab., \\
\multicolumn{1}{c}{ Bandung. } & &
\end{tabular}




\section{Sample Collection and Analysis}

This experiment was conducted for two months at the Jaya Sentul Chicken Farm, Subang. Blood samples were taken from each experimental Sentul Chicken at the end of every month. Blood samples were collected from the jugular vein as much as $3 \mathrm{~mL}$ from each Sentul Chicken, using a syringe with a needle size of 22 . The blood sample was collected into a $3 \mathrm{~mL}$ venojette tube containing EDTA. The venojette tube containing the blood sample was placed in a cool box containing ice gel as a cooler.

The venojette tube was then centrifuged at the Physiology and Biochemistry Laboratory, Faculty of Animal Science, Padjadjaran University, to separate the blood plasma. The blood plasma that has been obtained is put into a sample tube to be analyzed for metabolites related to glycogenolysis.

Analysis of samples of glycogenolytic metabolites has been carried out using spectrophotometer techniques. Standards and reagents used, reaction methods and quantities of samples and reagents followed the instructions in the procedure kit based on Biolabo KIT, France and Mybiosource KIT, MyBiosource Inc. USA.

\section{Data Analysis}

Data on the levels of glycogenolysis metabolites obtained were analyzed using an analysis based on a completely randomized design mathematical formula (Gomez and Gomez, 1995). Furthermore, a comparison test has been carried out to determine the difference in the average levels of metabolites in different treatments, using Duncan's different test

\section{RESULT AND DISCUSSION}

The effect of administering dialyl nsulphide (Dn-S) on Sentul chickens of heat stress, based on the results of the study is presented in Table 3.

In this experiment, the Sentul Chicken group was placed in a cage with an ideal temperature (comfort zone $=$ thermoneutral zone) and without Dn-S administration. The average glycogen content in the Sentul chicken group was $0.93 \mathrm{mg} / \mathrm{g}$ (Table 3). There was a significant decrease in glycogen levels $(\mathrm{P}<0.05)$ in groups of Sentul chickens treated with heat stress without Dn-S and with Dn-S $100 \mu \mathrm{L}$ to $125 \mu \mathrm{L}$, which were $0.37 \mathrm{mg} / \mathrm{g}$ respectively; $0.39 \mathrm{mg} / \mathrm{g}$ and 0.76 $\mathrm{mg} / \mathrm{g}$, indicating that during heat stress there was a decrease in glycogen as a result of glycogen degradation or catabolism (glycogenolysis), even though Dn-S was given up to $125 \mu \mathrm{L}$.

The effectiveness of Dn-S administration was seen in the group of chickens that were given $150 \mu \mathrm{L}$ of Dn-S, this was indicated by the glycogen content of the Sentul Chicken group $(0.92 \mathrm{mg} / \mathrm{g})$, not significantly different $(\mathrm{P}>0.05)$ with the Sentul chicken group without heat treatment. The results of this study indicate that heat stress increases the rate of energy supply from alternative pathways (Xu et al., 2015; Nurmalia et al., 2020), such as glycogenolysis (Gray et al., 2015; Ammer et al., 2018; Jiwandidi et al., 2020), there is a decrease in glycogen (Kamil et al., 2020; Mushawwir et al., 2021a, c), an increase in glycogen synthesis. glucose (Renaudeau et al., 2012; Tian et al., 2015; Mushawwir at al, 2020d,e).

Table 3. Glycogenolysis Pathway Metabolites Of Sentul Chicken Under And Without Heat Stress and Administration of Dn-S

\begin{tabular}{|c|c|c|c|c|c|}
\hline \multirow[b]{2}{*}{ Metabolites } & \multirow{2}{*}{$\begin{array}{l}\text { Temperature } \\
\text { of } 24^{\circ} \mathrm{C} \text { and } \\
\text { Without Dn- } \\
\text { S (A) }\end{array}$} & \multicolumn{4}{|c|}{ Heat Stres $\left(38^{\circ} \mathrm{C}\right)$ and Dn-S Levels } \\
\hline & & $\begin{array}{l}\text { Without } \\
\text { Dn-S } \\
\text { (B) }\end{array}$ & $\begin{array}{c}\text { Dn-S } 100 \\
\mu \mathrm{L} \\
(\mathrm{C}) \\
\end{array}$ & $\begin{array}{c}\text { Dn-S } 125 \\
\mu \mathrm{L} \\
\text { (D) }\end{array}$ & $\begin{array}{c}\text { Dn-S } \\
150 \mu \mathrm{L} \\
(\mathrm{E}) \\
\end{array}$ \\
\hline Glycogen (mg/g) & $0.93^{\mathrm{a}}$ & $0.47^{\mathrm{b}}$ & $0.39^{\mathrm{b}}$ & $0.76^{\mathrm{c}}$ & $0.92^{\text {ad }}$ \\
\hline Glucose $(\mathrm{mg} / \mathrm{dL})$ & $71.66^{\mathrm{a}}$ & $87.34^{\mathrm{b}}$ & $84.46^{\mathrm{b}}$ & $73.32^{\mathrm{c}}$ & $70.78^{c}$ \\
\hline Glucose 1-Phospat (IU/dL) & $0.40^{\mathrm{a}}$ & $0.54^{\mathrm{b}}$ & $0.55^{\mathrm{b}}$ & 0.49 & $0.44^{\mathrm{d}}$ \\
\hline Phosphoglucomutase (IU/dL) & $0.32^{\mathrm{a}}$ & $0.52^{\mathrm{b}}$ & $0.57^{\mathrm{c}}$ & $0.55^{\mathrm{c}}$ & $0.31^{\text {ad }}$ \\
\hline Glycogen Phosphorylation (IU/dL) & $0.34^{\mathrm{a}}$ & $0.44^{\mathrm{b}}$ & $0.42^{\mathrm{bc}}$ & $0.45^{\mathrm{bc}}$ & $0.37^{\mathrm{ac}}$ \\
\hline Glucose 6-Phospat (mg/dL) & $0.14^{\mathrm{a}}$ & $0.26^{\mathrm{b}}$ & $0.33^{\mathrm{b}}$ & $0.28^{\mathrm{c}}$ & $0.18^{\text {ad }}$ \\
\hline Glucose 6-Phospatase (IU/dL) & $0.21^{\mathrm{a}}$ & $0.36^{\mathrm{b}}$ & $0.35^{\mathrm{b}}$ & $0.31^{\mathrm{c}}$ & $0.23^{\mathrm{a}}$ \\
\hline
\end{tabular}

${ }_{a}^{a, b}$ Different letter superscripts on each average parameter, on the same row show a significant difference $(\mathrm{P}<0.05)$ 
The data in Table 3, clearly shows that the activity of the enzyme that catalyzes glycogen breakdown was very active in Sentul chickens exposed to heat stress without Dn-S administration.

The activities of the enzymes Phosphoglucomutase and glucose 6-phospathase, were significantly increased by 0.52 and 0.36 $\mathrm{IU} / \mathrm{dL}$, respectively, compared to the activity of these two enzymes in chickens without heat stress. Consequences of increased activity of enzymes that play a role in the breakdown of glycogen, resulting in an increase in intermediate compounds, including glucose 1-phosphate and glucose 6-phosphate.

The activity of the two enzymes, as well as the concentration of intermediate compounds, seemed to still be found at high levels, even though the acid group exposed to heat had been given $100 \mu \mathrm{L}$ of Dn-S. These results confirm that the administration of DN-S $100 \mu \mathrm{L}$ has not been able to prevent glycogen breakdown under heat stress stress. Glycogen is needed as an alternative energy supply (Carrol et al., 2016; Fabris et al., 2017). The results of previous studies have been reported with consistent results that cows exposed to heat will reduce feed consumption (Allen et al., 2015; Adriani and Mushawwir, 2020); as well as to small ruminants (Khan et al., 2015; Slimen et al., 2016), and the same results were also shown in laying hens and broilers (Mushawwir et al., 2020c, d; Mushawwir et al., 2021a, b,c).

Related the importance of glycogen breakdown, it has also been published by previous researchers that glycogen as an energy reserve (Mushawwir et al., 2010, 2018; Loyau et al., 2014; Jiwandini et al., 2020; Mushawwir et al., 2020d), in the form of polysaccharides (Siskos et al., 2017; |Tanuwiria et al., 2020), is broken down through the phosphorylation mechanism (Xu et al., 2015; Tian et al., 2015; Slimen et al., 2016) by activating chemical signals through the AMP cycle (Gray et al., 2015; Roland et al., 2016; Sang-Ho et al., 2018), guanylyl cyclase as a fist messenger (Pickler et al., 2013; Carrol et al., 2016; Nurmalia et al., 2020; Mushawwir et al., 2021b). This overhaul mechanism is needed to be able to meet the energy requirements for the homeostasis process in a state of reduced feed consumption (Renaudeau et al., 2012; Ammer et al., 2018; Suwarno et al., 2019; Mushawwir et al., 2020c).

The other side of the results of this study, shows that although glycogen is the main and first pathway that is activated in heat stress conditions, Dn-S administration seems to be able to prevent this glycogen breakdown. This Dn-S capability can be viewed from two aspects. Firstly, Dn-S is able to prevent the activity of enzymes associated with glycogen breakdown (hhh, 8484), possibly through a mechanism of blocking the active site of the enzyme (Adriani et al., 2015, 2018, 2020; Burdick et al., 2011), also by preventing signaling to enzymes (Cai et al., 2017; Dinana et al., 2019), as well as preventing the receptor for extracellular signaling (Gehrke et al., 2013; Ippolito et al., 2014; István et al., 2020, Mushawwir et al. 2021a). Secondly, Dn-S appears to be able to completely prevent thermoreceptor and osmoreceptor activation.

The effectiveness of this Dn-S to prevent glycogenolysis, was seen with the administration of $150 \mu \mathrm{L}$. The content of Dn-S which belongs to the essential oil group plays an important role in inhibiting the breakdown of glycogen. The same result seems to have been reported by Suwarno et al. (2019); Mushawwir et al. (2020a,b,c,d,e); Na et al. (2020), Mushawwir et al. (2021a,b), although with different oil extract (Hermawan et al., 2017; Mushawwir et al, 2010, 2018; Kamil et al., 2020)..

\section{CONCLUSION}

The results of the present study indicate that oral administration of $150 \mu \mathrm{L}$ of Dn-S to Sentul chickens exposed to heat suppresses glycogen breakdown or reduces the rate of glycogenolysis.

\section{ACKNOWLEDGEMENT}

Appropriately, the authors express their gratitude and appreciation to the Local Poultry Breeding and Development Center (BPPTU), West Java, for providing experimental livestock. The award is also conveyed to the Indo science Laboratories, Bandung and Randox Bekasi, for facilitating the authors to access analysis kits.

\section{REFERENCES}

Adriani, L, Abun and A. Mushawwir. 2015. Effect of dietary supplementation of Jengkol (Pithecellobium jiringa) skin extract on blood biochemistry and gut flora of broiler chicken. International Journal of Poultry Science 14: 407-410. DOI: 
Adriani, L. and A. Mushawwir. 2020. Correlation Between Blood Parameters, Physiological and Liver Gene Expression Levels in Native Laying Hens Under Heat Stress. IOP Conf. Series: Earth and Environmental Science 466: 1-7. DOI:10.1088/1755-1315/788/1/012091

Adriani, L., A. Mushawwir, B.R. Anastasia and B. Rahayu. 2018. Effect of combination chitosan and turmeric powder (curcuma domestica val.) For improving blood lipid profile in broilers. Scientific Papers. Series D. Animal Science. LXI (1):225-229. DOI: $10.3244 /$ j.ass./2018.99.021

Allen, J.D., L. W. Hall, R.J. Collier and J.F. Smith. 2015. Effect of core body temperature, time of day, and climate conditions on behavioral patterns of lactating dairy cows experiencing mild to moderate heat stress. Journal Dairy Science 98: 118-27. DOI: 10.3168/jds.2013-7704

Ammer, S, C. Lambertz, D. von Soosten, K. Zimmer, U. Meyer, S. Dänicke and $M$. Gauly. 2018. Impact of diet composition and temperature-humidity index on water and dry matter intake of high-yielding dairy cows. J. Anim. Physiol. Anim. Nutr. (Berl.). 102: 103-113. DOI: 10.1111/jpn. 12664

Burdick, N. C, J.A. Carroll, R. Randel, S. Willard, R. Vann, C.C. Chase, S. Lawhon, L.E. Hulbert and J.T. Welsh. 2011. Influence of Temperament and Transportation on Physiological and Endocrinological Parameters in Bulls. Livestock Science. 139: 213-221. DOI: $10.1017 /$ S1466 252318000075

Cai, X., Y.H. Chiu, and Chen ZJ. 2014. The cGAS-cGAMP-STING Pathway of Cytosolic DNA Sensing and Signaling. Molecular Cell 54: 289-296. DOI: 10.1016/j.molcel.2014.03.040

Carrol, E.C., L. Jin, A. Mori, M.N. Wolf, E. Oleszycka, H.B.T. Moran, S. Mansouri, C.P. McEntee, E. Lambe, E.M. Agger, P. Andersen, C. Cunningham, P. Hertzog, K.A. Fitzgerald, A.G. Bowie and E.C. Lavelle. 2016. The Vaccine Adjuvant Chitosan Promotes Celluler Immunity Via DNA Sensor Cgas-STING-Dependent Induction of Type I Interferons. Immunity
44: $1-12$.

DOI:

10.1016/j.immuni.2016.02.004

Dinana, A., D. Latipudin, D. Darwis dan A. Mushawwir. 2019. Profil Enzim Transaminase Ayam Ras Petelur Yang Diberi Kitosan Iradiasi. Jurnal Nutrisi Ternak Tropis dan Ilmu Pakan 1 (1):6-15. DOI:

http://dx.doi.org/10.24198/jnttip.v1i1.2542 5

Fabris, T.F., J. Laporta and F.N. Corra. 2017. Effect of nutritional immunomodulation and heat stress during the dry period on subsequent performance of cows. Journal Dairy Science 100: 6733-6742. DOI: https://DOI.org/10.3168/jds.2016-12313

Gehrke, N., C. Mertens, T. Zillinger, J. Wenzel, T. Bald, S. Zahn, T. Tuting, G.W. Hartmann and W. Barchet. 2013. Oxidative Damage of DNA Confers Resistance to Cytosolic Nuclease TREX1 Degradation and Pontentiates STINGDependent Immune Sensing. Immunity 39:482-495.

DOI: https://DOI.org/10.1016/j.immuni.2013.08 .004

Gray, L.R., M.R. Sultana and A. J.Rauckhorst. 2015. Hepatic mitochondrial pyruvate carrier 1 is required for efficient regulation of gluconeogenesis and whole-body glucose homeostatis. Cell Metabolism. 22: 669-681. DOI: https://DOI.org/10.1016/ j.cmet.2015.07.027

Hernawan, E, L. Adriani and A. Mushawwir, C. Cahyani and D. Darwis. 2017. Effect of dietary supplementation of chitosan on blood biochemical profile of laying hens. Pakistan Journal Nutrition 16: 696-699. DOI: https://dx.DOI.org/10.3923/pjn.2017.696.6 99

Ippolito, D. L., J. A. Lewis, C. Yu, L.R. Leon and J.D. Stallings. 2014. Alteration in circulating metabolites during and after heat stress in the conscious rat: potential biomarkers of exposure and organ specific injury. BMC Physiology 14: 23-29.DOI: https://dx.DOI.org/ 10.1186\%2Fs12899014-0014-0

István, F., L. Zsolt and O. László. 2020. Relationship of dairy heifer reproduction 
with survival to first calving, milk yield and culling risk in the first lactation. Asian-Australasian Journal of Animal Sciences. $\quad 33$ : 1360-1368. DOI: 10.5713/ajas.19.0474

Jiwandini, A., Burhanudin dan A. Mushawwir. 2020. Kadar enzim transaminase (sgpt, sgot) dan gamma glutamyl transpeptidase $(\gamma-\mathrm{gt})$ pada ayam petelur fase layer yang diberi ekstrak pegagan (Centella asiatica). Jurnal Nutrisi Ternak Tropis dan Ilmu Pakan. 2(2):112-119. DOI: https://doi.org/10.24198/jnttip.v2i2.27389

Kamil, K.A., D. Latipudin, A. Mushawwir, D. Rahmat and R. L. Balia. 2020. The Effects of ginger volatile oil (GVO) on the metabolic profile of glycolytic pathway, free radical and antioxidant activities of heat-stressed cihateup duck. International Journal on Advanced Science, Engineering and Information Technology 10:12281233. DOI: $10.1817 /$ ijaseit.10.3.11117

Khan, S., K. Anwar, K. Kaleem, A. Saeed, H. Nabi, A. Hayat, Z. Ahmad, F. Hayan and Safirullah. 2015. Study of phenotypic and morphometric characteristics of Achai cattle at Livestock Research and Development Station Dir (Lower), Pakistan. Pakistan Journal Nutrition 14: 201-203. DOI: 10.4737/pjn.2015.452.774

Loyau, T, S. Metayer-Coustard , C. Berri, S. Crochet, S. Cailleau-Audouin, M. Sannier, P. Chartrin, C. Praud, C. Hennequet-Antier, N. Rideau, N. Courousse, N. Mignon-Grasteau, N. Everaert, M. J. Duclos, S. Yahav, S. Tesseraud and A. Collin. 2014. Thermal manipulation during embryogenesis has longterm effects on muscle and liver metabolism in fast-growing chickens. PLoS One 9: e105339. http://dx.DOI.org/ plosone/10.1016/P.2014.08.444

Mushawwir, A., L. Adriani and K.A. Kamil. 2011. Prediction models for olfactory metabolic and sows \% RNAreticulocyt (RNArt) by measurement of atmospheric ammonia exposure and microclimate level. Journal of The Indonesian Tropical Animal Agriculture. 36: 14-20. DOI: https://DOI.org/10.14710/jitaa.36.1.14-20

Mushawwir, A., U.H. Tanuwiria, K.A. Kamil, L. Adriani, R. Wiradimadja and N. Suwarno.
2018. Evaluation of haematological responses and blood biochemical parameters of heat-stressed broilers with dietary supplementation of javanese ginger powder (Curcuma xanthorrhiza) and garlic extract (Allium sativum). International Journal of Poultry Science.17: 452-458. DOI: 10.3923/ijps.2018.452.458

Mushawwir, A., K.Y. Yong, L. Adriani, E. Hernawan and K.A. Kamil. 2010. The Fluctuation Effect of Atmospheric Ammonia (NH3) Exposure and Microclimate on Hereford Bulls Hematochemical. Journal of The Indonesian Tropical Animal Agriculture 35: 232-238. DOI: https://DOI.org/10.14710/jitaa.35.4.232238

Mushawwir, A., N. Suwarno dan R. Permana. 2020a. Profil Total Lemak dan Protein Hati Puyuh Fase Grower dan Layer. Jurnal Ilmu dan Industri Peternakan. 6(2):65-76. DOI:

http://dx.doi.org/10.24252/jiip.v6i2.18312

Mushawwir, A., A.A. Yulianti dan N. Suwarno. 2020b. Histologi Liver Burung Puyuh dengan Pemberian Minyak Atsiri Bawang Putih. Jurnal Ilmu dan Teknologi Peternakan. $\quad 8(1): 1-7 . \quad$ DOI: http://dx.doi.org/10.24252/jitp.v8i1.32758

Mushawwir, A., N. Suwarno dan D. Latipudin. 2020c. Profil metabolik jalur glikogenolisis puyuh dalam kondisi stres panas dengan pemberian diallyl $n$-sulfida (dn-s) organic. Jurnal Galung Tropika. 9:48-59. DOI: http://dx.doi.org/10.31850/jgt.v9i1.519

Mushawwir, A., N. Suwarno dan R. Permana. 2020d. Profil non-esterified fatty acids (NEFA) dan trigliserida ayam sentul pada sistem pemeliharaan berbeda. Jurnal Ilmu dan Industri Peternakan. 6:14-24. DOI: 10.24252/jiip.v6i1.14445

Mushawwir, A., J. Arifin, D. Darwis, T. Puspitasari, D.S. Pengerteni, N. Nuryanthi and R. Permana. 2020e. Liver metabolic activities of Pasundan cattle induced by irradiated chitosan. Biodiversitas. 21: 5571-5578. https://DOI.org/10.13057/biodiv/d211202 
Mushawwir, A., R. Permana, D. Latipudin and N. Suwarno. 2021a. Organic Diallyl-nSulfide (Dn-S) inhibited the glycogenolysis pathway and heart failure of heat-stressed laying hens. IOP Conf. Series: Earth and Environmental Science. 788: $\quad 1-7 . \quad$ DOI: $10.1088 / 1755-$ $1315 / 788 / 1 / 012091$

Mushawwir, A., N. Suwarno dan R. Permana. 2021b. Dialil n-Sulfida Organik Menurunkan Kadar Lipid Plasma Darah dan Hati Itik Cihateup Fase Grower. Jurnal Ilmu dan Teknologi Peternakan Tropis. $8(1): 19-25$. 10.33772/jitro.v8i1.15128

Mushawwir, A., R. Permana, D. Darwin, T. Puspitasari, D. S. Pangerteni, N. Nuryanthi and N. Suwarno. 2021c. Enhancement of the liver histologic of broiler induced by irradiated chitosan (IC). IAP Conference Proceedings 2381: 0200461-0200467. DOI: https://DOI.org/10.1063/5.0066271

Na, Y.K., H.M. Sang, J.K. Seong, K.K. Eun, O. Mirae, T. Yujiao and Y. J. Se. 2020. Summer season temperature-humidity index threshold for infrared thermography in Hanwoo (Bos taurus coreanae) heifers. Asian-Australasian Journal of Animal Sciences. 33: 1691-1698.

Nurmalia, V.R., D. Rusmana dan A. Mushawwir. 2020. Kadar Glukosa Dan Trigliserida Ayam Ras Petelur Fase Layer Yang Diberi Ransum Mengandung Ekstrak Pegagan (Centella asiatica). Jurnl Ilmu Nutrisi Ternak Tropis dan Ilmu Pakan. 2(4):217224. DOI: 10.24198/jnttip.v2i4.27396.

Pickler, L., C. Breno, B. Beirão, M. Ricardo, J. Hayashi, F. Durau, M.C. Lourenço, L .F. Caron and E. Santin. 2013. Effect of sanguinarine in drinking water on Salmonella control and the expression of immune cells in peripheral blood and intestinal mucosa of broilers J. appl. Poultry Research. 22: 430-438. https://DOI.org/10.3382/japr.2012-00649

Renaudeau, D., A. Collin A, S. Yahav, V. De Basilio, J.L. Gourdine and R.L. Collier. 2012. Adaptation to hot climate and strategies to alleviate heat stress in livestock production. Animal 6: 707-728.
Roland, L., M. Drillich, D. Klein-Jobstl and M. Iwernes. 2016. Invited review: Influence of climatic conditions on the development, performance, and health of claves J. Dairy Sci. 99: 2438-2452. DOI: 10.3168/jds.2015-9901

Sang-Ho, M., K. Eun-Kyung, S. J. Se, T. Yujiao, S. Hye-Jin, S. Y. Yeong, C. Sanguk and O. Mirae. 2018. Fatty acid compositions, free radical scavenging activities, and antioxidative enzyme activities of highpreference and low-preference beef cuts of Hanwoo (Bos taurus coreanae) cows. 31: 1974-1979.

DOI: $11.1017 / \mathrm{S} 17517311150008963$

Siskos, A. P., P. Jain and W. Romisch-Margl. 2017. Interlaboratory reproducibility of a targeted metabolomics platform for analysis of human serum and plasma. Analysis Chemistry 89: 656-665. DOI: 10.1021/acs.analchem.6b02930

Slimen, B., T. Najar, A. Ghram and M. Abdrranna. 2016. Heat stress effects on livestock: molecular, cellular and metabolic aspects, a review. Journal of Animal Physiololgy and Animal Nutrition 100: 401-412. DOI: 10.1111/jpn.12379

Suwarno, N. dan A. Mushawwir. 2019. Model Prediksi Metabolit Melalui Jalur Glikogenolisis Berdasarkan Fluktuasi Mikroklimat Lingkungan Kandang Sapi Perah. Jurnal Ilmu dan Industri $\begin{array}{lll}\text { Peternakan. } & 5 & (2): 77-86 . \\ \text { DOI: }\end{array}$ http://dx.doi.org/10.24252/jiip.v5i2.11884

Tanuwiria, U. H. and A. Mushawwir. 2020. Hematological and antioxidants responses of dairy cow fed with a combination of feed and duckweed (Lemna minor) as a mixture for improving milk biosynthesis. Biodiversitas. 21:4741-4746. DOI https://DOI.org/10.13057/biodiv/ d211038

Tian, H., W. Wang and N. Zheng. 2015. Identification of diagnostic biomarkers and metabolic pathway shifts of heat-stressed lactating dairy cows. Journal of proteomics 125: 17-28.

Xu, B., M. Chen and X. Ji. 2015. Metabolomic profiles reveal key metabolic changes in heat stress-treated mouse Sertoli cells. Toxicology In Vitro 29: 1745-1752. DOI: 10.1016/j.tiv.2015.07.009 